Silva, E.I.; Lima, I.B. O potencial econômico e turístico da pesca esportiva na Amazônia setentrional. Revista Brasileira de Ecoturismo, São Paulo, v.7, n.4, nov2014-jan2015, pp.779-803.

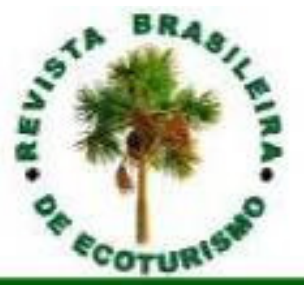

\title{
O potencial econômico e turístico da pesca esportiva na Amazônia setentrional
}

\author{
The economic and tourism potentiality of sport fishing in the \\ northernmost Amazonia (Brazil)
}

\author{
Eliane Inácio da Silva, Ismar Borges de Lima
}

\begin{abstract}
RESUMO
A pesca esportiva é praticada justamente por aquelas pessoas que têm como motivações o 'lazer', a 'recreação', as 'viagens', e as 'atividades' que fogem ao tradicional 'praia', 'mar', e 'sol'. Os praticantes da pesca esportiva buscam praticar um 'hobby' que os leva a experiências e vivências únicas nas áreas ribeirinhas da Amazônia. Além da sua importância como atividade alternativa econômica para vilas de pescadores profissionais, deve-se acrescentar ainda que a 'pesca esportiva' tem uma significativa relevância ecológica devido ao seu baixo impacto nas espécies pescadas, e, por ser praticada por grupos pequenos em trechos de florestas e de rios, isso facilita o controle da capacidade de carga e de impactos que a atividade poderia vir a acarretar na região. Por meio deste estudo buscou-se registrar aspectos, contexto e dinâmicas da pesca esportiva no município de Caracaraí, bem como de sua potencialidade econômica e compreender se a mesma pode ser desenvolvida de forma sustentável pelos grupos que dela participam e ,ou, são por ela afetados, entre eles: empresários, pescadores profissionais ribeirinhos, e as vilas no município, em particular, no Baixo Rio Branco, em Roraima. A pesquisa teve uma orientação quali-quantitativa cuja coleta de dados se deu por meio de visitas técnicas in loco, com o uso de triangulação metodológica que incluiu técnicas de observação participante, realização de entrevistas, aplicação de questionários semiestruturados, e registros pictográficos. Os pescadores e comunidades ribeirinhas foram o foco da investigação.

PALAVRAS-CHAVE: Pesca-Esportiva; Trade Turístico; Segmentação; Viabilidade Econômica; Ribeirinhos da Amazônia; Sustentabilidade; Roraima.
\end{abstract}

\section{ABSTRACT}

Sport fishing is practiced by precisely those people whose motivations the 'leisure', a 'recreation', to 'travel' and 'activities' that are beyond the traditional 'beach', 'sea' and 'sun'. Practitioners seek sportfishing practice a 'hobby' that leads to unique experiences and experiences in the riverine areas of the Amazon. Besides its importance as an economic alternative for activity professionals villages of fishermen, and one should also add that the 'sport fishing' has significant ecological importance due to its low impact on the species caught, and, being practiced by small groups in excerpts forests and rivers, making it easy to control the load capacity and the likely impacts that the activity could eventually result in the region. Through this study it was sought to report the aspects, context, and dynamics of the sportfishing in the Caracarai County, as well as to identify evidences of its economic viability in the municipality and to understand whether the activity can be developed by groups who participate in it and, or, are affected by it, which includes: entrepreneurs, riverbank professional fishermen, and local residents of the villages, in the Baixo Rio Branco region, in Roraima. The research had a qualitative and quantitative guidance in which data collection took place through technical site visits, using methodological triangulation which included participant observation, interviews, application of semi-structured questionnaires, and pictorial records. The focus was fishermen and riverbank communities.

KEYWORDS: Sport Fishing; Tourism Trade; Segmentation; Economic Viability; Amazonian Riverbank Villages; Sustainability; Roraima. 


\section{Introdução}

Turismo é o setor da economia com grande potencial para os próximos anos, com a tendência de crescimento desse setor, destaca-se a pesca esportiva, pois é um seguimento turístico que proporciona grandes emoções ao turista e um contato direto com a natureza, propiciando uma aproximação plena entre 'indivíduo' e 'natureza', um fato que remonta aos primórdios do homem, mas, hoje em dia, uma ocorrência menos frequente em virtude do avanço do 'urbano' sobre o 'rural' e o 'natural'. São, portanto, reencontros com a natureza cada vez mais em demanda na busca de uma evasão das rotinas estressantes das cidades.

A globalização trouxe a modernização, e com ela o dinamismo e frenesi das cidades, rotinas estafantes, mas tudo isso não tirou das pessoas a simplicidade de observar a natureza e fazer coisas simples como pescar em um rio qualquer para distrair e, ou, competir com outras pessoas em uma pesca esportiva, por exemplo. Além disso, é um tipo de atividade que favorece também uma relativa interação e vivências entre 'visitantes' e os 'povos ribeirinhos'. O turismo em Roraima possibilita uma relação direta com os ribeirinhos do Baixo Rio Branco podendo conhecer sua cultura manifestada na agricultura, no extrativismo, na caça e na pesca. Assim, é possível por meio do turismo, visitar comunidades para observar e vivenciar o cotidiano e rotinas dessas populações.

A pesca esportiva tem-se revelado uma atividade de grande impacto na economia de diversos países e regiões no que se refere à geração de renda e emprego, alavancando esse segmento turístico (ALBANO; VASCONCELOS, 2013; STOECKL, GREINER, MAYOCCHI, 2006) com estimativas de 730 milhões de praticantes desse tipo de pesca pelo mundo (ARLINGHAUS et al., 2009). Muito embora esteja em ascensão como segmento turístico, a pesca esportiva - apesar de considerada de baixo impacto - não está livre de críticas na literatura, pois a sua prática e gestão inadequadas podem vir a torná-la mais impactante do que outros tipos de pesca, pois na pesca esportiva as pessoas acabam buscando ecossistemas considerados "críticos" para as diversas fases do ciclo de vida e reprodução das espécies de peixes (ALBANO; VASCONCELOS, 2013; COOKE; COWX, 2004), além de permitir uma interação - mesmo que curta e sazonal - entre visitantes e os residentes locais.

Destaca Bartholo (2009) que uma densidade de olhares pode ajudar na compreensão do sentido de proximidade entre o elemento 'comunidade' e 'visitante', com a possibilidade de se apontar políticas e ações que favoreçam a materialização de vivências e experiências mútuas, dinâmicas, e inter-relações desejáveis, considerando-se a diversidade sociocultural de grupos humanos que habitam a Amazônia, sendo isso uma das matérias-primas para o fortalecimento das diferentes modalidades e práticas turísticas na região, em particular, aquelas que são alicerçadas pelos princípios da sustentabilidade e protagonizadas pelas comunidades.

Na leitura de Coriolano (2009, p.284),

O turismo comunitário é aquele em que as comunidades de forma associativa organizam arranjos produtivos locais, possuindo o controle efetivo das terras e das atividades econômicas associadas à exploração do turismo. Nele o turista é levado a interagir com o lugar e 
com as famílias residentes, seja de pescadores, ribeirinhos, pantaneiros ou de índios.

Santos Júnior e Ribeiro (2006) corroboram tal visão ao citar uma pesquisa de opinião realizada com lideranças comunitárias da Amazônia pelo World Wildlife Fund, WWF, em 2001, em que "há um reconhecimento generalizado de que a região amazônica abriga vastos territórios com uma ampla diversidade cultural, social e ecológica. Portanto, é natural que possua várias vocações produtivas...atividades extrativistas da floresta; ecoturismo; mineração; e agricultura sustentável' (p.17).

No entanto, o avanço do agronegócio pelas monoculturas, e o consequente desmatamento, bem como o adensamento populacional, são ameaças à manutenção de áreas naturais que vêm sofrendo significativas reduções na Amazônia Legal, em especial no Pará e Mato Grosso, e sabidamente são intervenções antropogênicas de grande impacto que comprometem os ambientes naturais prístinos necessários para um equilíbrio ambiental, bem como comprometem as riquezas paisagísticas naturais que servem de atrativos turísticos, entre eles, os recursos hídricos - rios, riachos, igarapés, e lagos - utilizados para a pesca esportiva.

No contexto deste trabalho envolvendo a pesca esportiva e seu potencial econômico e para a sustentabilidade regional, levantou-se a seguinte perguntapesquisa norteadora desta investigação, servindo de guia para a manutenção do foco e das abordagens aqui propostas: a pesca esportiva pode vir a ocorrer em contraposição à pesca profissional amenizando os impactos negativos no meio ambiente?

Diante dos questionamentos e abordagens aqui propostos, a pesquisa tem como objetivos específicos:

- Apresentar o contexto e a percepção dos residentes do Baixo Rio Branco, bem como dos empresários atuantes no município de Caracaraí sobre a pesca esportiva e suas potencialidades para 0 turismo e o desenvolvimento local;

- Identificar qual a viabilidade de a pesca esportiva se tornar uma atividade econômica alternativa para os pescadores profissionais ter uma renda durante o período do defeso, também conhecido como piracema, que é o período da desova dos peixes.

Para alcançar os objetivos propostos, faz-se necessário informar, sensibilizar e introduzir os empresários da pesca esportiva e os pescadores profissionais locais e respectivas comunidades sobre a possibilidade de desenvolvimento de um novo conceito de atividade turística nos rios amazônicos centrado na 'pesca esportiva' de baixo impacto ambiental e, preferencialmente, com a soltura do peixe fisgado; um segmento que sirva de alternativa à pesca profissional em larga escala sendo tão vantajosa em termos rentabilidade aos ribeirinhos. Com isso, o desenvolvimento do turismo de pesca esportiva mostrase promissora como atividade a ser praticada no ócio, tempo livre das pessoas, servindo também como opção de lazer tornando-se um elemento estruturante de 
um novo contexto sócio-recreativo, pois aproxima 'visitantes' das rotinas e realidade das comunidades ribeirinhas, além de promover algum 'aquecimento' na economia local com a entrada de recursos em razão da atividade, seja com o pagamento de guias, aluguéis de canoas, e, ou, compra de produtos na região. Além disso, a pesca esportiva pode servir também como estratégia para se superar a sazonalidade turística na baixa temporada, atraindo levas de visitantes durante esses períodos.

A atividade pode ser de base participativa por meio da sensibilização de pescadores profissionais locais a se engajarem neste tipo de pesca, servindo como guias especializados provendo informações essenciais e orientações sobre a região, seus rios, espécies e cardumes de peixes, e técnicas de pesca fluvial aos turistas. A pesca esportiva possui ainda um papel ampliado de relevância socioambiental e educativo uma vez que também pode ser usado para ações de conscientização dos ribeirinhos ao por em evidencia a importância de se preservar as espécies aquáticas e o meio ambiente aquático tão essenciais para a segurança alimentar das comunidades.

\section{Relativizando conceitualmente o turismo e a prática da 'pesca esportiva'}

De acordo com Brasil (2001, p.23), os segmentos e classificações turísticas podem ser determinados a partir dos elementos de identidade, oferta e também por certas características. Seguem abaixo algumas definições disponíveis na literatura sobre turismo sustentável e turismo de pesca, duas das principais preocupações e objeto de investigação neste estudo, sendo que 'sustentabilidade' é o conceito "pano de fundo" que permeia e fundamenta a discussão sobre a viabilidade ecológica da pesca esportiva.

I. Turismo sustentável - Mais do que um tipo, é um jeito de planejar a atividade turística, proporcionando a revitalização local, o resgate da auto-estima, geração de empregos para a população. Tudo isso organizado para favorecer a preservação ambiental e das demais estruturas da região (o Patrimônio Cultural, a organização de eventos etc.). A participação da comunidade facilita a identificação de oportunidades de trabalho e qualificação profissional. BRASIL, 2001;

II. Turismo de pesca - Compreende as atividades turísticas que se efetivam em função da prática da pesca amadora: operação e agenciamento, transporte, hospedagem, alimentação, recepção, recreação e entretenimento, eventos e atividades complementares.

As definições para os diversos seguimentos de turismo também foram consideradas como parte da revisão da literatura sobre tipologia, discorrendo-se sobre as que se seguem abaixo, pois possuem vínculos mais diretos com a pesca esportiva, em particular, o turismo rural e o ecoturismo. No caso do primeiro, em razão da pesca esportiva ocorrer em áreas rurais, distantes dos grandes centros urbanos, e no contexto de uma ruralidade ribeirinha; no caso do ecoturismo, os vínculos existem em função de a pesca esportiva ser de baixo impacto, e de contribuir - mesmo que de forma não tão ampla - com a geração de renda e de emprego em nível local, além do que os praticantes da pesca 
esportiva atuam em áreas de elevado valor paisagístico e natural, e acabam também contemplando e usufruindo das belezas desses locais.

I. Turismo rural - $\mathrm{O}$ conjunto de atividades turísticas desenvolvidas no meio rural, comprometido com a produção agropecuária, agregando valor a produtos e serviços, resgatando e promovendo o patrimônio cultural e natural da comunidade. (MINISTÉRIO TURISMO, 2003, p.11). Na definição de Beni (1997), o turismo rural 'associa atividades naturais culturais típicas do meio rural, como andar a cavalo, pesca, etc. ocorre em sítios e fazendas' (BENI, 1997);

II. Ecoturismo - Denominação dada ao deslocamento de pessoas para espaços naturais delimitados e protegidos pelo Estado, iniciativa privada ou controlados em parceria com associações locais e ONGs. Pressupõe sempre uma utilização controlada da área com planejamento de uso sustentável de seus recursos naturais e culturais, por meio de estudos de impacto ambiental, estimativas da capacidade de carga e suporte do local, monitoramento e avaliação constantes, com plano de manejo e sistema de gestão responsável. É claro que todas as atividades previstas no turismo ecológico podem, em geral, ser realizadas, desde que rigorosamente observadas as restrições de uso desses espaços. No Brasil, o ecoturismo, além de ser comumente confundido com o turismo ecológico ou de natureza, está até o momento circunscrito a poucos casos, levando em conta que as nossas áreas de conservação e proteção ambiental ainda não dispõem de uma política integrada e de um planejamento estratégico de uso e ocupação voltados especificamente para o turismo (BENI, 1999).

$\mathrm{Na}$ Seção a seguir, serão discutidos os principais aspectos sobre o turismo de pesca e da pesca esportiva no Brasil tendo como base um relato histórico e as principais leis que normatizam e regulamentam essa atividade no país, e essa leitura se faz necessária como parte da revisão da literatura a fim de se entender o arcabouço legal que permeia a pesca esportiva, portanto, fundamental para se subsidiar a problematização do tema.

\section{Turismo de Pesca: Pesca Esportiva no Brasil}

A construção do marco conceitual de 'turismo de pesca esportiva' fundamenta-se em dois aspectos principais: os movimentos turísticos que ocorrem em territórios específicos, em razão da presença de espécies singulares de peixes; e o perfil do turista de pesca, em função de sua motivação caracterizada pelo usufruto dos recursos naturais de forma sustentável, de acordo com as peculiaridades das duas atividades - pesca e turismo - e com as legislações que as regem.

No Brasil, o primeiro documento direcionado à pesca foi o Decreto $\mathrm{n} . \stackrel{0}{ }$ 447, de 19 de maio de 1846 (revogado), que pioneiramente buscou regulamentar a permissão da pesca, bem como a catalogação de embarcações e buscou efetivar a devida matrícula de pescadores atuantes nesse ramo de atividade (BRASIL, 2008, p.32). 
Contudo foi em 28 de fevereiro de 1967, com o lançamento do DecretoLei $n .{ }^{\circ} 221$, que a atividade de pesca foi conceituada e regulamentada sendo oficialmente definida, classificada, e categorizada de acordo com sua finalidade, entendo-se que: a "pesca é todo ato tendente a capturar ou extrair elementos, animais ou vegetais que tenham na água seu normal ou mais freqüente meio de vida", podendo a pesca efetuar-se com fins comerciais, desportivos, ou científicos:

- Pesca Comercial - atos de comércio na forma da legislação em vigor;

- Pesca Desportiva - praticada com linha de mão, por meio de aparelhos de mergulho permitidos por autoridade competente e que não seja como atividade comercial;

- Pesca Científica - exercida unicamente com fins de pesquisa por instituições ou pessoas devidamente habilitadas para esse fim;

- Pesca Amadora - O licenciamento é a forma de controlar a exploração dos recursos pesqueiros e implementação de planos e gestão para fiscalizar garantir os estoques.

Como destacado por Solha (2009) em relação à legislação que rege a pesca amadora, a licença para a mesma obrigatória. Licenciando-se, o pescador está garantindo a prática legal da atividade válida em todo o território nacional. As normas estaduais, mesmo assim, devem ser respeitadas (BRASIL, 2008, p.23). No entanto, estão ficando dispensados aposentados, ou seja, homens maiores de 65 anos e mulheres acima de 60 anos, desde que não sejam membros de clubes ou associações de pesca amadora; além desses, menores de 18 anos e indivíduos que realizam pesca com linha de mão ou caniço - sem molinete - às margens de rios, riachos, e lagos, ou seja, pescadores desembarcados, também estão dispensados de possuírem licença. Conforme Solha (2009), a Federação estabelece normais gerais de limite de pesca em quota, definida em quilos, bem como os tamanhos mínimos do pescado; há também normas específicas vigentes em cada estado e município que devem ser observadas e seguidas pelos pescadores.

A legislação preocupa-se não só com a espécie alvo da pesca, bem como com os fatores que venham a propiciar a formação de estoque pesqueiro nos recursos hídricos do país com a garantia da reprodução e existência das espécies de peixes, em particular, durante o defeso, conhecido também como piracema. A manutenção da qualidade do meio ambiente aquático, sua preservação e conservação, são preocupações da legislação vigente. Para tanto a Constituição da República Federativa do Brasil de 05 de outubro de 1988 em seu artigo 225 afirma,

Todos têm direito ao meio ambiente ecologicamente equilibrado, bem de uso comum do povo e essencial do à sadia qualidade de vida, impondo-se ao poder público e à coletividade e o dever de defendê-lo e preservá-lo para os presentes e futuras gerações. 
Desse modo, entende-se que a pesca esportiva - regulamentada por meio de decretos e pela legislação - é uma atividade permissível de ser praticada pelos indivíduos, sejam ribeirinhos, turistas, e segmentos do setor privado desde que se faça de maneira correta, com técnicas e procedimentos que atendam às leis e tenham um viés sustentável, ou seja, que ela tenha um impacto mínimo no meio ambiente e nas espécies, além de favorecer condições para o bem estar das populações locais e a conservação dos biomas.

A fim de se fazer valer a legislação e atribuir poderes de decisão do setor, em 2003, por meio da Lei 10.683, foi criado o Ministério da Pesca com a missão de efetivar políticas públicas para o fomento da atividade de pesca e aquicultura no país. Assim, foi criado o 'Projeto Amazônia Aqüicultura e Pesca Plano de Desenvolvimento Sustentável', a fim de se estimular a criação de peixes em cativeiros para a conservação das espécies nativas. $O$ foco também se restringe em proteger a floresta das extrações de madeira e da pecuária extensiva.

Agripa e Krischke (2006) frisam que vários aspectos institucionais das políticas de sustentabilidade, considerando-se as origens sociais dos grupos, das comunidades, e da luta deles para a melhoria da qualidade de vida e para a garantia de uma fonte alimentar mais estável, representem elementos essenciais a serem trabalhados na busca por uma sustentabilidade.

No entanto, as práticas e visões de orientação sustentável dependem também do fortalecimento das políticas ambientais, uma mudança de paradigma que se fortaleceu após a realização do Encontro Mundial das Nações Unidas sobre Meio Ambiente e Desenvolvimento, a ECO-92, em que cinco principais documentos foram aprovados tendo dezenas de países signatários dos mesmos visando a acatar os novos desafios socioambientais a serem enfrentados pelos chefes de estado e pela humanidade como um todo.

A disposição cultural de governos, mercado, e setores da sociedade civil na análise de suas origens e consequências das práticas de implementação, uma perspectiva inversa do consenso, qual seja, a de que os países ricos sejam os líderes na busca pelas respostas - ações, estratégias, inovação, e tecnologia - que tornem a idealização da sustentabilidade algo realizável, viável, exequível, e efetiva na redução dos impactos negativos causados pelo homem em escala global; assim, diante da luta de defesa pelo meio ambiente.

Em 2005, o Tratado de Kyoto foi assinado com o compromisso por parte dos países signatários, entre eles os industrializados e daqueles em via de desenvolvimento, visando a tomada de ações e políticas que promovessem a redução da emissão de gases poluentes, um tema polêmico devido à resistência dos Estados Unidos e de outras nações-líder de diminuírem seus índices de emissão de poluentes sob o pretexto de que isso afetaria a economia do país.

Nota-se, portanto, que em quase todos os setores cresce a preocupação com os recursos naturais, sua preservação, e conservação, em razão do aumento da conscientização ambiental e das ações de vários governos para resolver o problema, particularmente após a ECO-92, e, guiando-se pelas recomendações da Agenda 21. E com essa tendência mundial, a pesca esportiva não poderia ficar de fora devido à necessidade de se ter práticas mais sustentáveis para as comunidades e grupos residentes em áreas de inestimável valor ambiental, bem como para os adeptos e praticantes da mesma. 
Os praticantes de pesca esportiva são regidos por uma legislação de 'vanguarda ambiental', e alguns deles possuem conscientização e interesse na preservação das espécies mais cobiçadas, ajudando a fiscalizar os chamados 'paraísos ecológicos' da pesca. Por exemplo, em termos de 'legislação de vanguarda ambiental', cita-se a Lei 11.959, de 29 de junho de 2009, do governo federal, que dispõe sobre a Política Nacional de Desenvolvimento da Aquicultura e da Pesca, regulando as atividades pesqueiras, em seu Capítulo I, estabelece que:

Art. $1^{\circ}$ Esta Lei dispõe sobre a Política Nacional de Desenvolvimento Sustentável da Aquicultura e da Pesca, formulada, coordenada e executada com o objetivo de promover:

I - o desenvolvimento sustentável da pesca e da aquicultura como fonte de alimentação, emprego, renda e lazer, garantindo-se o uso sustentável dos recursos pesqueiros, bem como a otimização dos benefícios econômicos decorrentes, em harmonia com a preservação e a conservação do meio ambiente e da biodiversidade;

II - o ordenamento, o fomento e a fiscalização da atividade pesqueira;

III - a preservação, a conservação e a recuperação dos recursos pesqueiros e dos ecossistemas aquáticos;

IV - o desenvolvimento socioeconômico, cultural e profissional dos que exercem a atividade pesqueira, bem como de suas comunidades.

$\mathrm{Na}$ legislação brasileira a pesca é regulamentada basicamente pelo Decreto -Lei no 221, de 28/2/67 e posteriores alterações. No Estado de São Paulo o Decreto no 31.663, de 05/7/90, criou o Conselho Estadual da PescaCONPESC, com atribuição entre outras de implantar o Plano Estadual da Pesca, observando as políticas agrícolas e ambientes (ZIMERMANN, 2007, p.33).

De acordo com Zimermann (2007), o 'turismo de pesca' vem se destacando como opção de desenvolvimento para determinadas regiões, especialmente pela capacidade de promover a conservação dos recursos naturais nos destinos turísticos. Para tanto, o planejamento e a operacionalização desse segmento devem ocorrer de forma integrada entre gestores públicos de turismo, órgãos oficiais de meio ambiente, comunidades locais, prestadores de serviços turísticos e vários outros parceiros do meio privado.

A pesca esportiva pode se tornar uma fonte significativa de renda para 0 Estado por meio de impostos, ressaltando que: a pesca esportiva incentiva o desenvolvimento dos chamados "pesqueiros", ou seja, locais especialmente projetados para a prática da pesca esportiva, onde milhares de pessoas podem passar horas de lazer trazendo assim novas formas econômicas. Deve ainda ser aproveitada também como uma das atividades de suporte ao desenvolvimento sustentável, pois está diretamente ligado à necessidade de preservação dos rios, lagos, açudes e represas, das espécies de peixes, inclusive para a sua própria continuidade. Conforme Zimermann (2007, p.36) por estes motivos devese dar atenção e se desenvolver esta relevante fonte de recreação, esporte, e de geração de renda, aperfeiçoando-a principalmente na modalidade pesque e solte. 
Como o próprio nome diz, 'pesque e solte' é o ato de pescar, capturar o peixe, admirá-lo, fotografá-lo e devolvê-lo à água zelando para que os impactos sofridos não comprometam sua sobrevivência. É fundamental entender que na pesca esportiva o maior atrativo para o turista pescador é o peixe, de preferência em quantidade e peso adequados, em torno de 12 a $15 \mathrm{~kg}$, geralmente o tucunaré-açu é o favorito dos turistas na Amazônia.

A atitude de devolver o peixe com vida à água, independentemente de estar dentro ou não das medidas estabelecidas pela legislação, deve ser praticada por todas as pessoas que dependem da manutenção da pesca esportiva, como garantia de lazer ou emprego (PNDPA - Programa Nacional Desenvolvimento da Pesca Amadora, 2010).

A esportiva é uma modalidade de pesca amadora, a portaria $n-4$ de 10 de março de 2009 do IBAMA - que estabelece normas gerais para exercício da pesca amadora em todo território - no artigo $2^{\circ}$.,

I - Pesca Amadora - aquela praticada por brasileiros ou estrangeiros com a finalidade de lazer, turismo e desporto , sem finalidade comercial;

II - Pesca Esportiva - modalidade de pesca por brasileiros em que é obrigatória a prática do pesque e solte, sendo verdadeiro o direito à cota de transporte de pescadores, prevista na legislação.

Este decreto-lei foi praticamente revogado com o surgimento da lei no 11.959, que estabelece o novo marco para a pesca e aquicultura brasileira ao dispor sobre a política nacional de desenvolvimento sustentável da aquicultura e da pesca. Dessa forma, atualiza e moderniza os princípios súperos que discutem a pesca e a aquicultura inclusive a pesca amadora. E na seção I. Definido no Artigo 8ำ classifica pesca como sendo 'comercial' e 'não comercial':

\section{I - comercial:}

a) artesanal: quando praticada diretamente por pescador profissional, de forma autônoma ou em regime de economia familiar, com meios de produção próprios ou mediante contrato de parceria, desembarcado, podendo utilizar embarcações de pequeno porte;

b) industrial: quando praticada por pessoa física ou jurídica e envolver pescadores profissionais, empregados ou em regime de parceria por cotas-partes, utilizando embarcações de pequeno, médio ou grande porte, com finalidade comercial.

\section{II - Não Comercial:}

Cientifica: quando praticada por pessoa física ou jurídica com finalidade de pesquisa cientifica;

Amadora: quando praticada por brasileiro ou estrangeiro, com equipamentos ou petrechos previstos em legalização especifica , tendo por finalidade o lazer ou o desporto; 
De subsistência: quando praticada com fins de consumo doméstico ou escambo sem fins de lucro e com a utilização de petreches previstos em legislação especifica.

A proposta deve contemplar os objetivos da atividade turística que são a de promover o desenvolvimento para beneficiar as comunidades receptivas, incentivar a conservação do ambiente e atender às expectativas do turista pescador. Segundo dados da EMBRATUR (2005), a pesca e o turismo são duas vocações do Brasil que podem ser potencializadas mediante aos seguintes fatores:

Se trabalhadas conjuntamente, haja vista a dimensão territorial, extensão costeira e hídrica e a diversidade de ictiofauna do país. Embora existam relatos da atividade de pesca com finalidade de lazer no Brasil desde meados do século XX, somente a partir de 1998 passou a ser trabalhado oficialmente como um segmento turístico, com 0 incentivo do Programa Nacional de Desenvolvimento da Pesca Amadora - PNDPA, executado pelo Ministério do Meio Ambiente/Instituto Brasileiro de Meio Ambiente e dos Recursos Naturais Renováveis - IBAMA e pelo Ministério do Esporte e Turismo/Instituto Brasileiro de Turismo EMBRATUR (p. 25).

\section{Contextualizando Roraima no Turismo de Pesca: História e a Pesca Esportiva}

Segundo Silva e Silva (2005, p.3), o Estado de Roraima foi criado com a Constituição de 1988, e Roraima abriga em seu território extensas áreas de floresta, bem como savanas amazônicas, conhecidas regionalmente como 'lavrados'. Possui ainda rios em abundância, com cachoeiras, corredeiras e praias apropriadas ao ecoturismo. O estado tem a maior parte de seu território acima da linha do Equador (GUIA RORAIMA ,2010).

O Estado selecionou duas regiões para receber os investimentos do Programa de Desenvolvimento do Ecoturismo na Amazônia Legal PROECOTUR, quando ainda estava ativo pelo Ministério do Meio Ambiente até 2006/2007. O primeiro situado no nordeste do estado está o Parque Nacional do Monte Roraima e os lavrados roraimenses, e o segundo localizado na área de Caracaraí, cidade localizada às margens do rio Branco, o principal do estado. No Parque Nacional do Monte Roraima está o ponto mais setentrional do país, a Serra do Caburaí, próximo à tríplice fronteira Brasil-Venezuela-Guiana (BOAS, 2008, p.37).

O Parque ostenta formações geológicas de rara beleza, envolvidas por florestas, e acolhe nascentes de rios importantes da região, como a área do Cotingo que exibe várias quedas d'água ao longo de seu curso. Nas rochas do parque é possível ver também registros de povos pré-históricos que habitaram a região. Segundo o Guia Roraima (2010), o Monte Roraima é um dos pontos mais elevados do país, com 2.875 metros de altitude. Próximo ao parque está o município de Uiramutã e a Serra do Sol, outro ponto culminante, com 2.400 metros de altitude. 
Ao sul do Parque Nacional está a Serra do Tepequém, encravada no lavrado roraimense, no município de Amajari. Trata-se de uma formação vulcânica, em cujo topo há uma cratera onde funcionou o primeiro garimpo de diamantes do estado. $O$ antigo caminho usado pelos garimpeiros para subir seus 1.400 metros de altitude funciona hoje como uma trilha para apreciadores de trekking. Estando situada em uma região de nascentes, a Serra do Tepequém tem ainda as cachoeiras do Paiva e do Funil como atrativos adicionais (GUIA RORAIMA, 2010).

Para a compreensão do desenvolvimento do turismo em Roraima, assim como a pesca esportiva ou turismo de pesca. Requer uma análise entendendo a importância da pesca para o Estado, que vai além de uma simples atividade econômica e compreende os aspectos sociais e culturais da região.

Nesse sentido é importante ressaltar que desde o início da humanidade, a pesca vem sendo praticada como uma atividade de subsistência do homem e em Roraima assim como em toda a Amazônia não é diferente. Conforme a Secretaria de Planejamento do Estado de Roraima a pesca é atualmente uma das principais atividades econômicas do Estado, geradora de empregos e renda.

\begin{abstract}
Além de ser uma importante atividade de subsistência para as comunidades tradicionais existentes na região. Além de sua notada relevância para a sustentação da população, a pesca predatória é também uma grande fonte de inspiração da cultura local, que diariamente se renova no vai e vem das embarcações, acompanhando o ritmo dos ciclos naturais do ensinamento passado de geração em geração (SEPLAN, 2001, p.08).
\end{abstract}

Entre os setores que fomentam a economia de Roraima destacam-se a agropecuária, o setor madeireiro, a pesca, funcionalismo público, e nos últimos anos o crescente aumento do setor turístico (FECOMERCIO, 2003, p.1).

Pode-se dizer que o turismo de pesca em Roraima se desenvolve a partir da visita de brasileiros e estrangeiros que vem em busca da prática da pesca esportiva terminam por fazer outros tipos de passeios, como navegar pelos rios e igarapés, onde se pode avistar a variada fauna da região, sobretudo de pássaros.

Nos roteiros ecológicos voltados para o turismo sustentável no Estado, os visitantes experimentam o contato direto com a natureza. Os passeios em canoa motorizada oferecem ao visitante a oportunidade de adentrar na floresta, com possibilidades de observação de diversas espécies animais e vegetais típicos desse ecossistema.

Ressalta-se que o portão de entrada do polo de Roraima para toda atividade econômica é a capital Boa Vista que conta com aeroporto internacional. Roraima pode ser percorrido de norte a sul pela BR-174, que, partindo de Manaus (AM), passa pela Capital e chega até a fronteira com a Venezuela, onde se conecta com outra estrada que vai até o Caribe venezuelano. Entre Manaus e Boa Vista, são 785 quilômetros de estradas, mas há trechos necessitando de manutenção, que dá acesso aos vários municípios do estado de Roraima. 
No Estado, os principais destinos de grande popularidade e apelo são as regiões da Serra do Tepequém e Monte Roraima, mas os atrativos não se limitam obviamente a dois lugares, tendo Roraima outras localidades de igual valor turístico, sem se falar do turismo indígena que pode ser praticado nas Terras Indígenas São Marco e na Raposa Serra do Sol. Com relação à prática do turismo de pesca, o mesmo tem sido praticado profissionalmente em Roraima mais intensamente nos últimos 10 anos, com destaque para a região do Baixo Rio Branco que recebe mensalmente dezenas de turistas estrangeiros (SEPLAN, 2001). Roraima ganhou destaque e visibilidade como destino para a prática da pesca esportiva quando figurou na 1a. posição ranking mundial, devido ao trabalho da empresa Água Boa Lodge, ficando à frente de destinos mais tradicionais como Canadá, Bahamas, Estados Unidos, e Nova Zelândia.

Muito embora Roraima disponha de um grande potencial para a pesca esportiva, políticas públicas e projetos por parte do poder público devem criar mecanismos e instrumentos para que as comunidades envolvidas possam se beneficiar mais equitativamente e diretamente do turismo de pesca esportiva, dando-se a devida relevância para o elemento 'humano' e 'social' neste segmento.

\section{Caracaraí no Contexto da Pesca Esportiva}

O município de Caracaraí, no Estado de Roraima, rico em biodiversidade, apresenta características favoráveis e um grande potencial para a atividade que nos momentos de folga podem optar por viagens para contemplar o meio ambiente natural, a flora e a fauna no Brasil e no mundo, no segmento da pesca esportiva pode ser praticada nos lagos e igarapés do Rio Branco, principal bacia hidrográfica do Estado.

Os rios, Branco, Anauá, Xeruini, Jufari, Água Boa, Anauá e Barauana, esses rios apresentam grandes quantidades e espécies de peixe, sem contar com a beleza exuberante, todos com suas particularidades. A perspectiva para 0 turismo de pesca esportiva é feita a partir do pressuposto de que o município de Caracaraí apresenta um rio rico em diversidade de espécies de peixes, tais como: tucunaré (Figura 1), pirarara (Figura 2), filhote, piraíba, jandiar e surubim. A pesquisa visa, portanto, averiguar se o município pode ser considerado com potencial para a pesca esportiva.

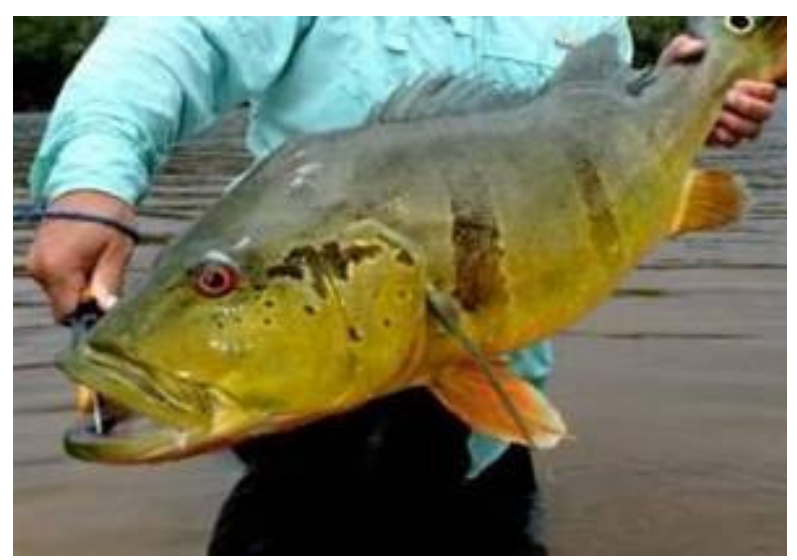

Figura 1: Tucunaré. Fonte: ipesque.com.

Figure 1: Tucunaré. Source: ipesque.com. 


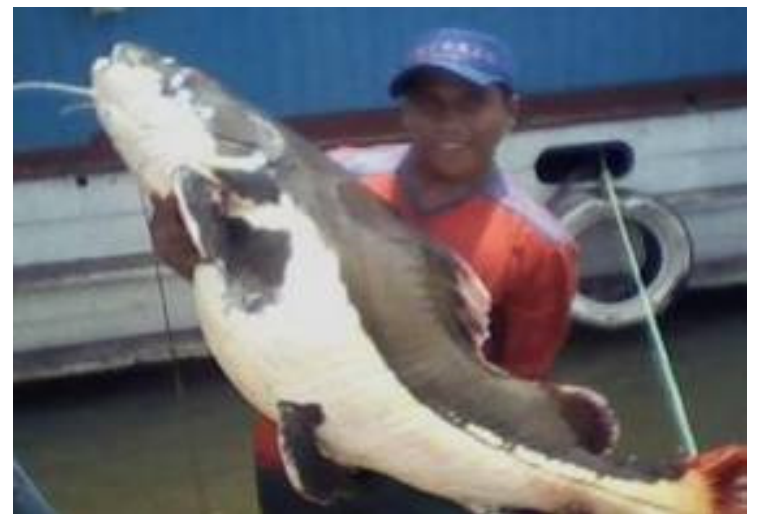

Figura 2: Pirarara conhecido também por Peixe-fera. Fonte: pescaemroraima.com.

Figure 2: Pirarara also known as Peixe-fera. Source: pescaemroraima.com.

\section{Turismo de Pesca: Potencialidade Turística da Pesca Esportiva no Município de Caracaraí}

Localizado no médio e baixo rio Branco, Caracaraí é a cidade porto do Estado de Roraima, com grande acesso fluvial que permitiu que o município se desenvolvesse entre as décadas de 1960 a 1980. Atualmente o acesso mais viável e fácil se dá pela BR 174, e o Rio Branco que era então a principal via de acesso ao Estado do Amazonas, passa a ser visto pelo turismo local como a "menina dos olhos" para a atividade turística de pesca esportiva, no intuito de gerar renda para a sede do município e para as vilas ribeirinhas do Baixo Rio Branco.

Caracaraí é conhecida regionalmente como 'Cidade Porto' por ter servido de local de embarque e desembarque de gado do estado em décadas passadas, um transporte que atualmente não é mais feito por via fluvial, mas por via terrestre pela BR-174. A construção e a pavimentação da rodovia possibilitaram uma nova dinâmica e configuração para Roraima, em particular, com ganhos e perdas em termos de ponto logístico para uma cidade beira-rio como Caracaraí. Contudo, as margens do rio Branco em Caracaraí são usadas significantemente para o atracamento de vários barcos vindos de regiões do interior, e para o transporte de combustível da PETROBRÁS no local, além de servir de ponto de partida para visitantes que usam o local para ter acesso ao Baixo Rio Branco. Conforme, o Censo do IBGE 2010, o total de habitantes do município é de 18.384 habitantes e na sede a população é de 10.910 habitantes, apresentando uma densidade demográfica de 0,38 hab./ $/ \mathrm{Km}^{2}$.

O município de Caracaraí limita-se ao Norte com os municípios de Iracema, Cantá e Bonfim, ao Sul com Rorainópolis, São João da Baliza e São Luis do Anauá Leste com Caroebe e República da Guiana e ao Oeste com o estado do Amazonas. Conforme Freitas (1997, p.88), o município de Caracaraí foi criado pela Lei Federal $n^{\circ} 2.495$, de 27 de Maio de 1955, com território desmembrado dos municípios de Boa Vista e Catrimani. Ocupa a maior área do Estado de Roraima com área de $47.623,6 \mathrm{Km}^{2}$, com participação em relação ao Estado de 21,15\% (IBGE,2010), e um IDH - Índice de Desenvolvimento Humano - de 0,702, sendo considerado médio pelo PNUD (2000, p.03). 
O distrito-sede de Caracaraí, desde sua fundação, tem uma vocação portuária no Estado e se destaca por ser o maior pólo pesqueiro de Roraima. Outrora era um simples campo destinado ao embarque de bovinos, com cerca de 1.900 residências instaladas, sendo seus habitantes empregados no comércio local, funcionários públicos, ou vaqueiros. Caracaraí, nome dado pelos indígenas a um pequeno gavião, comum na região, chamado de 'caracará', apresenta características favoráveis ao desenvolvimento do turismo em suas diversas modalidades (CARACARAÍ, 2008, p.10).

O município com suas belezas naturais e riquezas históricas e culturais tem um grande potencial turístico a ser desenvolvido, conta com uma grande riqueza cultural devido à miscigenação de raças e povos. Além disso, Caracaraí é privilegiada com fauna e flora exuberantes, corredeiras, rios, igarapés, praias e ilhas que revelam belos atrativos turísticos naturais bastante admirados nacional e internacionalmente, e ainda belos Parques Nacionais e Estações Ecológicas.

Nesse contexto o titulo "o paraíso da pesca esportiva" cai como luva para o município de Caracaraí (Figura 3), tendo em vista que nos últimos anos o município é uma das áreas mais procuradas por pescadores esportivos. Conta com hotéis de selva, situados no Baixo Rio Branco, disponibilizando inúmeras atividades a seus usuários como passeios, pescas, além da agradável e exuberante natureza, com a participação de pessoas das agrovilas ribeirinha como saci, Terra Preta, Lago Grande, Cachoeirinha, Caicubí, Canauini, que direta ou indiretamente estão envolvidas nessa atividade turística da pesca esportiva.

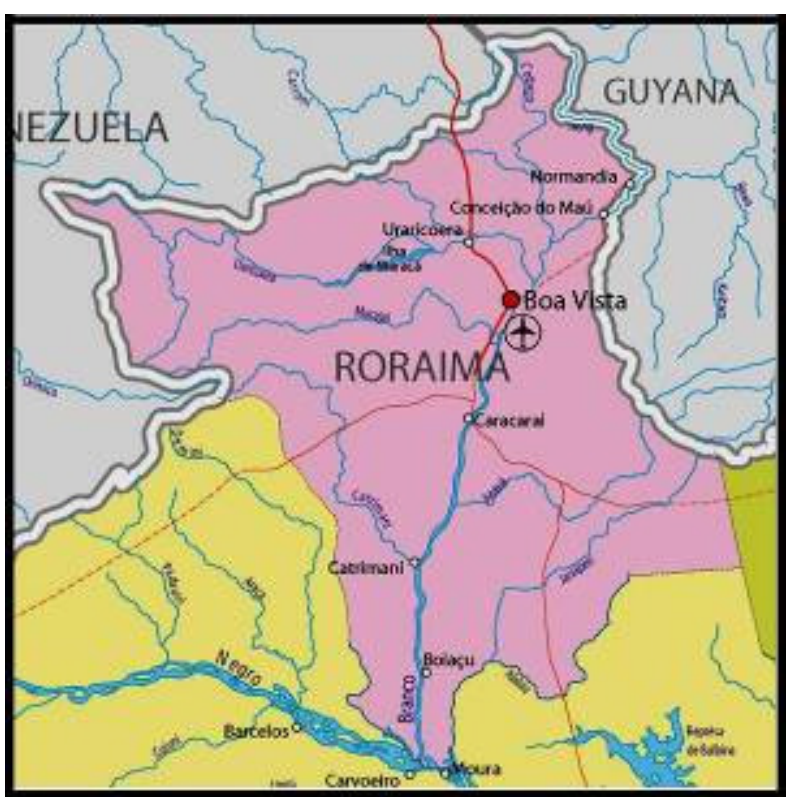

Figura 2: Mapa de Roraima, localização de Caracaraí e Boi Açu (Baixo Rio Branco). Fonte: EmbassyWorld.com.

Figure 2: Map of Roraima (Brazil), location and Caracaraí Boi Acu (Baixo Rio Branco). Source: EmbassyWorld.com.

Visando ao desenvolvimento do turismo da pesca esportiva no município e a necessidade de proteção ambiental foi criada e aprovada a Lei 378/02 de 17 de novembro de 2002, cujos Artigos $1^{\circ}$ e $2^{\circ}$ versam e regulamentam a prática da pesca esportiva no Baixo Rio Branco, mais especificamente na APA Xeriuini. 
Art. 1으 - Fica instituída a Licença de Pesca Esportiva da Área de Proteção Ambiental Xeriuini, de porte obrigatório para visitantes que tenham como fim a prática da pesca esportiva no interior de seus limites.

- A Licença de Pesca Esportiva terá a validade de seis meses a contar da data de sua emissão, devendo conter campos destinados à identificação do portador, e será validada mediante a apresentação de documento de identidade;

- O valor da Licença de Pesca Esportiva será de $\mathrm{R} \$ 25,00$ (vinte e cinco reais), recolhidos a crédito de conta específica do Fundo Municipal de Desenvolvimento Ambiental - FUNDAM;

São isentos do pagamento da Licença de Pesca Esportiva os menores de 14 anos e os maiores de 65 anos de idade que comprovarem essa condição.

Art. 2ㅇ - A receita oriunda da emissão de Licenças de Pesca Esportiva da Área de Proteção Ambiental Xeriuini destinar-se-á exclusivamente à organização, custeio, e manutenção das atividades de licenciamento, monitoramento e fiscalização ambiental do município de Caracaraí, Roraima.

\section{Procedimentos Metodológicos}

Os procedimentos metodológicos foram baseados em Dencker (2001, p.41 e 52) com a elaboração de um projeto de pesquisa qualitativo e quantitativo, com a adoção de técnicas e procedimentos de investigação em temas do turismo. A pesquisa foi desenvolvida com foco nos pescadores, as comunidades ribeirinhas, e os empresários do ramo em áreas do município, principalmente no Baixo Rio Branco e, também com coleta de dados na sede do município, devido sua posição estratégica logisticamente falando.

No seu aspecto qualitativo, a pesquisa busca obter dados e material descritivo para análise por meio de questionários, entrevistas, e observação participante, o que caracteriza uma triangulação na coleta de dados. Segundo Gil (2002, p.42) a parte descritiva de uma pesquisa tem como objetivo primordial obter detalhes objetivos e subjetivos das características de uma determinada população e, ou, de fenômenos, e, ou, identificar o estabelecimento de relações entre variáveis.

Utilizou-se da revisão bibliográfica com o intuito de analisar o processo de evolução do turismo e de suas modalidades a fim de se conhecer a realidade local e as potencialidades turísticas relativas à pesca esportiva, bem como compreender a dinâmica de trabalho e a visão dos empresários do ramo em Caracaraí.

No total foram 106 pessoas entrevistadas, sendo 6 (seis) empresários e 100 (cem) pescadores. Devido ao seu contingente populacional urbano ser mais concentrado, houve uma predominância de respondentes na sede urbana do que nas demais comunidades. Assim, foram entrevistados 60 (sessenta pescadores) da sede do município de Caracaraí. Os respondentes são pessoas que atuam ou que moram no Baixo Rio Branco, e se encontravam na sede do municípios e 40 (quarenta) respondentes nas Vilas. Desses, sendo 10 (dez) da 
comunidade de Sacaí, 5 (cinco) em Terra Preta, 2 (dois) em Lago Grande, 8 (oito) em Canauinin, 10 (dez) em Caicubí, e 5 (cinco) em Cachoeirinha.

Abaixo segue o detalhamento das comunidades de pescadores do baixo rio branco envolvidos com a pesca e, ou, com o turismo de pesca esportiva no município de Caracaraí, e relevante para esta pesquisa. A primeira comunidade é Sacaí (Figura 4), na margem direita do rio branco vila localizada em uma ilha, tem cinquenta e oito famílias, onde o acesso é fluvial, e é a única comunidade que não trabalha diretamente com o turismo de pesca esportiva, só com a pesca profissional e agricultura, onde a venda do pescado e do que produzem é principalmente para Manaus (AM) e Caracaraí.

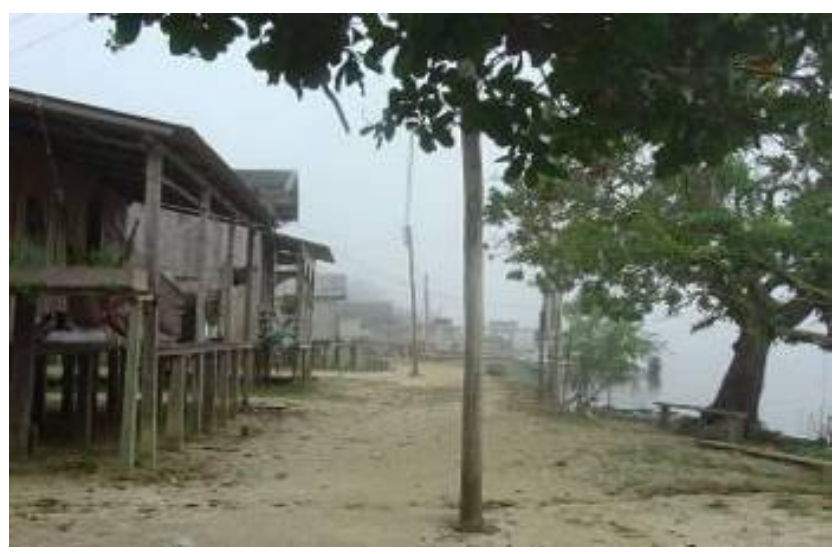

Figura 4: Vila de Sacai. Fonte: Secretaria do Meio Ambiente de Caracaraí.

Figure 4: Village SACAI. Source: Department of Environment Caracaraí.

Terra Preta (Figura 5) localiza-se à margem direita do Rio Xeriuini', residem trinta e sete famílias onde o meio de locomoção se dá por canoas, voadeiras ou por pequenos barcos de madeira motorizados, transportes individuais e de subsistência. A principal vertente do setor econômico é a área encontrada no turismo de pesca esportiva no zoneamento da micro-bacia do Xeriuini, em duas áreas ocupadas por empresas que trabalham no setor turístico.

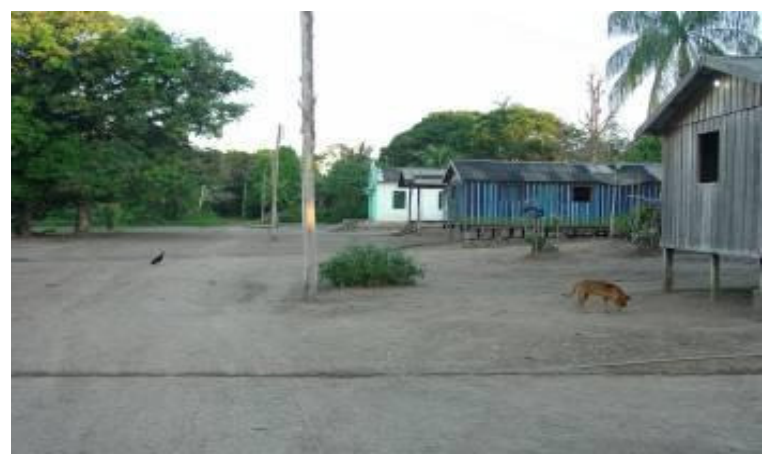

Figura 5: Vila de Terra Preta. Fonte: Secretaria do Meio Ambiente de Caracaraí.

Figure 5: Village Terra Preta. Source: Department of Environment Caracaraí.

Lago Grande (Figura 6) tem dezesseis famílias, uma área total de $8.829,99 \mathrm{~m}^{2}$. É uma agrovila integrada à unidade de Conservação Municipal, APA - Área de Preservação Ambiental do Xeriuini, criada pelo decreto 025/1999, 
de 8/12/1999, localizada no Rio Branco na foz que dá acesso às principais cidades e mercados da região, entre eles: Manaus, Barcelos e Caracaraí. Em Lago Grande, outras atividades produtivas são a agricultura e a atividade de extrativismo florestal, tais como frutos e sementes, e o pescado.

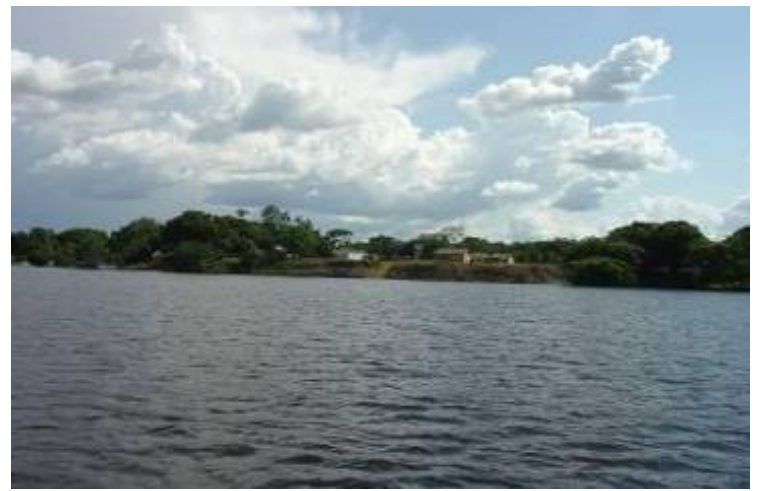

Figura 6: Vila de Lago Grande. Fonte: Secretaria do Meio Ambiente de Caracaraí.

Figure 6: Village Lago Grande. Source: Department of Environment Caracaraí.

Canauini (Figura 7) apresenta praticamente as mesmas características das demais vilas, atualmente com 32 (trinta e duas) famílias, comunidades de pescadores, que também trabalham no turismo de pesca, no rio Amajaú, onde duas empresas do amazonas estão operando nessa área.

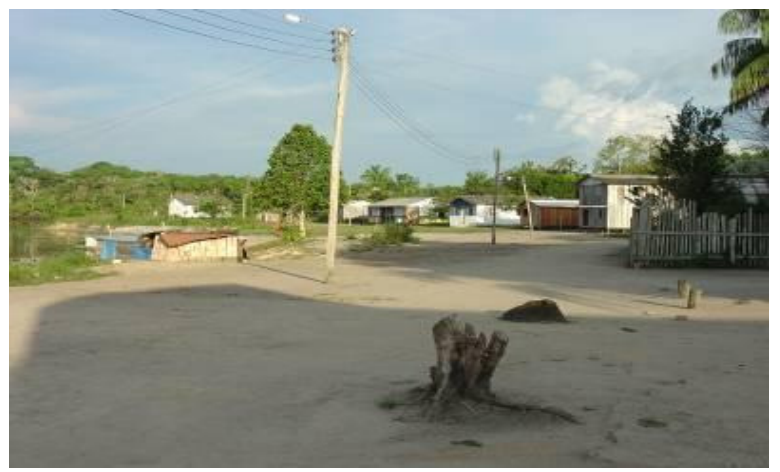

Figura 7: Canauini Fonte: Secretaria do Meio Ambiente de Caracaraí.

Figure 7: Canauini. Source: Department of Environment Caracaraí.

Caicubi (Figura 8) é a maior comunidade constituída de 105 (cento e cinco) famílias em 2012, tendo as mesmas características das demais comunidades, e está localizada no rio Jufari. Também na APA do Xeriuini.

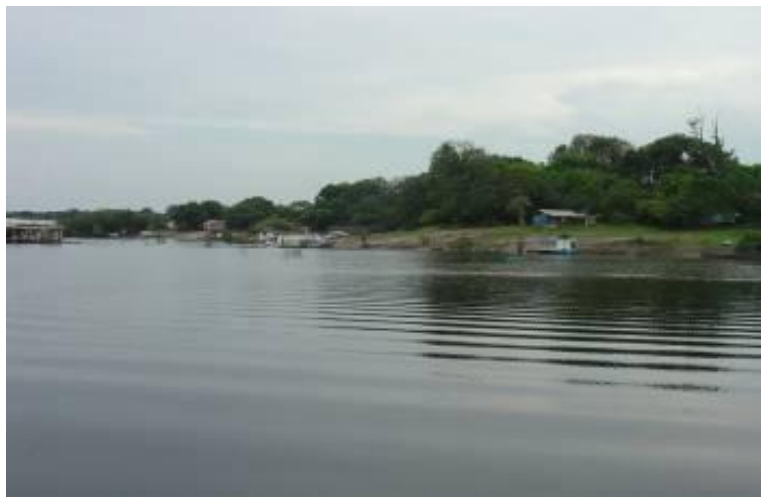

Figura 8: Caicubi. Fonte: Secretaria do Meio Ambiente de Caracaraí. Figure 8: Caicubi. Source: Department of Environment Caracaraí. 
A Vila Cachoeirinha (Figura 9) localizada à margem do Rio Amajaú, composta de 46 (quarenta e seis) famílias, e com uma área total de 161.818,69 $\mathrm{m}^{2}$, integrada à APA Xeriuini. Na Vila, a energia elétrica é produzida por motor (gerador), e as atividades mais relevantes são a agricultura, a pecuária, 0 extrativismo e a pesca comercial, além do turismo de natureza em virtude da pesca e dos safáris fotográficos que vêm crescendo gradativamente na região.

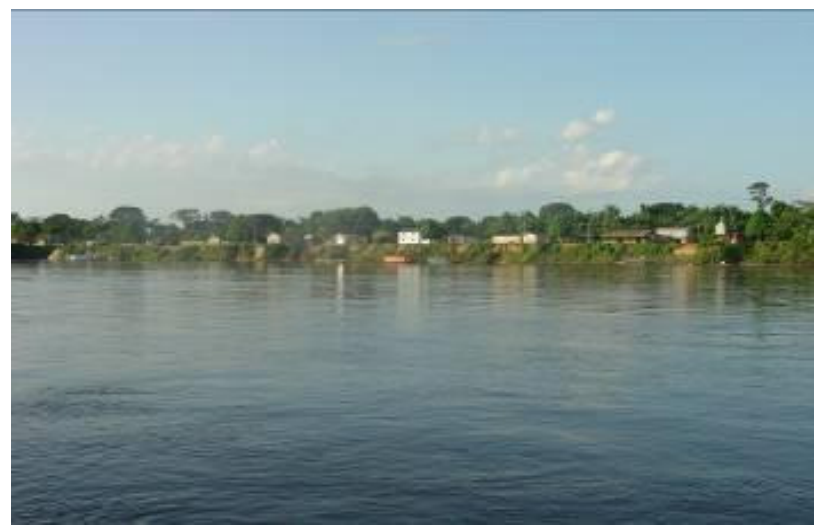

Figura 9: Vila de Cachoeirinha. Fonte: Secretaria do Meio Ambiente de Caracaraí.

Figure 9: Village Cachoeirinha. Source: Department of Environment Caracaraí.

Panacarica (Figura 10) é a ultima localidade do município de Caracaraí, já na divisa do rio branco com Rio Negro, sua população é de 19 (dezenove) famílias, mas a Vila possui uma população flutuante e encontra-se com esse número de residentes em declínio devido às cheias que alagam a região todos os anos no inverno, e por não ter escola, a distância torna-se um fator que tem motivado alguns moradores deixarem o local; migrantes que acabam indo para a sede do município, Caracaraí, ou para Barcelos e Manaus, buscando melhores condições de vida.

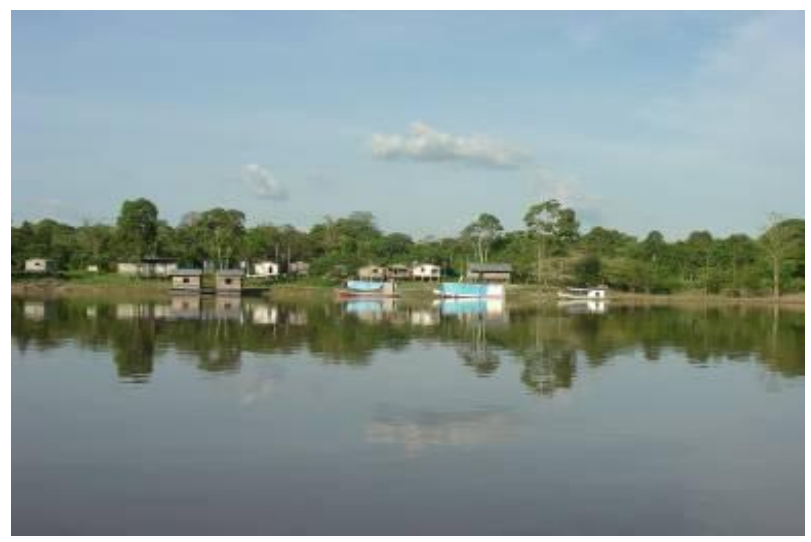

Figura 10: Vila de Panacarica. Fonte: Secretaria do Meio Ambiente de Caracaraí.

Figure 10: Village Panacarica. Source: Department of Environment Caracaraí.

O turismo de pesca esportiva desenvolvido no Baixo Rio Branco envolve a comunidade local, e a atividade é realizada em conjunto, por meio de rodízios, de modo que os residentes engajados no turismo se revezem em grupos de quatro a seis piloteiros das voadeiras, com saídas para a realização da pesca com turistas em intervalos de oito em oito dias. Cada voadeira transporta de 1 ou 
2 turistas, cujos valores da logística, guiamento, etc. oscila entre 200 dólares e 400 dólares dependendo da quantidade de dias e a complexidade da pesca a ser realizada. Os turistas usualmente buscam recompensar os piloteiros e residentes locais com gratificações e gorjetas, e esse reconhecimento pode servir como estímulo fazendo com que a comunidade fique cada vez mais envolvida no turismo de pesca.

A relevância desta pesquisa, além de contribuir para a literatura segmentada, também pode vir a propiciar benefícios aos pescadores, empresários, comunidade e aos estudiosos interessados na temática, possibilitando uma compreensão mais holística do contexto do turismo de pesca no município de Caracaraí. A pesquisa busca também oferecer subsídios para a esfera administrativa - o poder público municipal e estadual - que possam ser úteis no momento de se elaborar novas políticas públicas para o turismo de pesca esportiva como vetor de desenvolvimento local.

\section{Resultados e discussões}

Para melhor compreensão dos resultados a respeito do potencial e desenvolvimento da pesca esportiva como geração de renda para o município de Caracaraí, traçou-se primeiramente um perfil socioeconômico dos pescadores profissionais da pesca no município e das comunidades ribeirinhas. De acordo com os resultados, $70 \%$ dos pescadores entrevistados são do sexo masculino, e $30 \%$ do sexo feminino.

Quanto ao nível de escolaridade dos pescadores, 26\% são alfabetizados ou analfabetos funcionais, $16 \%$ não são alfabetizados, sendo que $25 \%$ têm o ensino fundamental, e $20 \%$ possuem ensino médio, e $13 \%$ nunca frequentaram a escola; a pesquisa revela que não há nenhum ribeirinho abordado com nível superior. A faixa etária dos pescadores varia entre 18 a mais de 40 anos.

De acordo com os pescadores entrevistados, o resultado sobre a renda familiar mensal onde 6\% ganham menos de um salário mínimo, 35\% um salário mínimo, 34\% de um a dois salários, e 25\% ganham mais de 3 salários por mês. Pode-se afirmar que a renda familiar desses pescadores é muito inferior ao esperado conforme relatado pelos próprios pescadores que afirmam que às vezes a despesa deles é maior do que arrecadam com as atividades produtivas locais, incluindo a pesca. Uma situação ainda mais limitante para aquelas famílias que não têm barco próprio e têm de pescar com outros pescadores, ganhando porcentagens do peixe que tiram do rio.

Nota-se que 3\% trabalham a menos de um ano, e que $30 \%$ atuam como pescadores profissionais compreendendo um período de 01 a 05 anos; 25\% trabalham neste tipo de atividade entre 5 a 10 anos; e $42 \%$ já exercem a profissão há mais de 10 anos.

De acordo com 97\% dos pescadores, o Baixo Rio Branco tem grande potencial para a pesca esportiva por causa das variedades de peixes e pelo fato de o Rio Branco ter vários afluentes com estoque pesqueiro; e 3\% mostraramse céticos dizendo 'não' com relação ao potencial do turismo de pesca esportiva. Esses respondentes deixaram claro que não sabiam do que se tratava a pesca esportiva por não estarem engajados com essa atividade turística. 
Conforme os pescadores, o maior potencial para a 'pesca esportiva' centra-se em alguns lugares específicos no Baixo Rio Branco, entre eles: a Vilas de Terra Preta, Lago Grande, Cachoeirinha, Caicubí, e Canaueni (Tabela 1).

Tabela 1: Dados e porcentagem de indicações sobre qual localidade no município de Caracaraí apresenta maior potencial para o turismo de pesca esportiva.

Table 1: Data and information on what percentage of locality in the municipality of Caracaraí has great potential for tourism sportfishing.

\begin{tabular}{lccc}
\hline $\begin{array}{c}\text { Qual a localidade no município de Caracaraí apresenta } \\
\text { maior potencial para o turismo de pesca esportiva? }\end{array}$ & (f) & (\%) \\
\hline Lago Grande & Rio Xeriuini & 27 & 27,00 \\
Terra Preta & Rio Xeriuini & 25 & 25,00 \\
Cachoeirinha & Rio Xeriuini & 20 & 20,00 \\
Canaueni & Rio Amajaú & 15 & 15,00 \\
Caicubí & Rio Jufarí & 13 & 13,00 \\
\hline Total & & $\mathbf{1 0 0}$ & $\mathbf{1 0 0 , 0 0}$ \\
\hline
\end{tabular}

Conforme os respondentes, $82 \%$ os pescadores afirmam que a pesca esportiva tem 'sim' um viés ecológico, porque os turistas - em especial os estrangeiros - têm muito cuidado e preocupação com o peixe fisgado, não o levam para o consumo, e depois de capturado, eles soltam novamente o peixe no rio. Foi relatado também pelos ribeirinhos que esses turistas não jogam lixo no rio nem nas praias. Contudo, $18 \%$ responderam que 'não' há uma preocupação ecológica com a região e o meio ambiente, pois alguns turistas em particular - os de Roraima, não tem o mesmo cuidado com 0 rio que 0 observado com outros turistas.

Com relação aos pontos positivos, $62 \%$ dos respondentes relataram que o 'turismo de pesca esportiva' poderia gerar muitos empregos diretos e indiretos no município, e $38 \%$ afirmaram ainda que o aumento do fluxo de visitantes em razão da pesca esportiva faz com que mais capital seja deixado regionalmente por conta da compra de produtos para a pesca, de aluguel de veículos, incluindo barcos, pela compra de gêneros alimentícios, algo que acaba movimentando o comércio local, etc., bem como por meio da arrecadação de impostos.

Quando foi perguntado aos pescadores profissionais ribeirinhos quais os pontos negativos que o turismo de pesca esportiva poderia trazer para as comunidades ribeirinhas, $44 \%$ disseram que a pesca é negativa porque os turistas têm privilégios de pescar nas áreas onde têm várias espécies de peixes e só é permitido suas entradas, sendo proibidas a entrada dos pescadores profissionais, e $56 \%$ não apontaram nenhum fato negativo a respeito da pesca esportiva.

Por fim, percebendo que o município de fato tem um potencial turístico para a pesca esportiva, considerado fonte complementar de renda para os pescadores profissionais, 65\% responderam que os turistas deixam dinheiro no município e geram emprego contratando pessoas locais. Porém, 35\% responderam que os benefícios financeiros diretos da pesca esportiva não são tantos assim, pois as empresas só contratam dois ou três pescadores para o trabalho com o turismo, não havendo uma maior distribuição desses recursos entre os demais residentes locais.

Quando questionados sobre quais rios de Caracaraí apresentam maior 
potencial para se desenvolver o turismo de pesca esportiva, 33,36\% citaram o rio Água Boa, com maior potencial turístico, seguido, de os Rios Anauá, com $16,66 \%$, e o Rio Branco, com 16,66\%; o Rio Xeriuini, com 16,66\%, e o Rio Jufarí, também com $16,66 \%$, conforme a pesquisa, todos os rios demonstram ter potencial para a pesca esportiva devido as variedades de peixes e por possuírem belezas naturais que per se também têm grande apelo como atrativo turístico.

Conforme a Tabela 2, as principais espécies de peixes explorados pelos turistas na pesca esportiva são, em primeiro lugar, o tucunaré com $50 \%$, seguido do filhote e pirarara com 33,33\%, e, por último, o surubim com 16,67\%.

Tabela 2: Dados e porcentagem de indicações sobre quais as principais espécies de peixe explorado na pesca esportiva.

Table 2: Data and information on what percentage of the major exploited fish species in fishing.

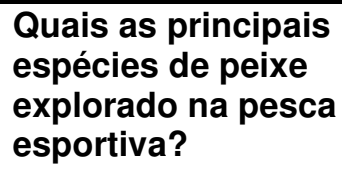

\begin{tabular}{lll}
\hline -Tucunaré & 03 & 50,00 \\
-Pirarara e Filhote & 02 & 33,33 \\
-Surubim & 01 & 16,67 \\
\hline Total & 06 & $\mathbf{1 0 0 , 0 0}$ \\
\hline
\end{tabular}

Quando os empresários foram indagados sobre qual a contribuição em termos de recursos financeiros que o turismo de pesca possibilita ao município ou à comunidade, muitos respondentes ficaram relutantes em responder, talvez por não saberem um valor mais exato, mas conforme os dados tabulados, $66,66 \%$ afirmaram que a arrecadação gira em torno de $R \$ 300$ mil reais por temporada e, consequentemente, gerando empregos localmente e movimentando o comércio local, além da arrecadação de impostos pela prefeitura municipal e pelo estado. Já 33,34\% dos entrevistados não souberam ou não quiseram responder.

Quando questionados sobre a expectativa do turista que pratica o turismo de pesca esportiva em Caracaraí, ou seja, se a expectativa deles é atendida plenamente, os empresários responderam por unanimidade que 'sim', somando-se assim um percentual de $100 \%$.

Segundo os empresários, $66,66 \%$ afirmaram que o manejo pelo pescador de pesca esportiva é correto na hora do manuseio com o pescado, todavia $16,67 \%$ disseram que 'não', pois o peixe se debate e dificulta o manuseio, e 16,67\% afirmaram nunca ter prestado atenção nesse fato.

Com relação ao fato de a comunidade estar inserida ou 'não' no turismo de pesca esportiva, 83,33\% acreditam que a atividade é inclusiva, e 16,67\% disseram ainda não ter usufruído dos benefícios da pesca esportiva. Conforme os resultados dos questionários, $83,33 \%$ dos entrevistados dizem que a pesca esportiva ameniza os impactos predatórios existentes no município de Caracaraí, por outro lado, 16,67\% dizem que 'não'. 
Nas entrevistas com os empresários, foi indagado se o turismo de pesca esportiva promovia o desenvolvimento local no contexto socioambiental, e o resultado foi de que 'sim' por parte de $100 \%$ dos entrevistados, pois acreditam que o turismo - independente de sua modalidade - contribui em diferentes níveis para o desenvolvimento local e para a preservação do meio ambiente se praticado de forma consciente e com base nos princípios da sustentabilidade.

\section{Considerações finais}

Uma das grandes contribuições desta pesquisa sobre a pesca esportiva na sede do município de Caracaraí e nas comunidades ribeirinhas do Baixo Rio Branco, é mostrar o contexto e a percepção dos grupos envolvidos na atividade, em particular, os pescadores profissionais ribeirinhos e os empresários. A pesquisa demonstra que esses grupos possuem grande expectativa com relação ao potencial econômico da pesca esportiva para a região, bem como acreditam no seu papel ecológico.

Cabe ressaltar que mesmo os pescadores desconhecendo a prática do turismo de pesca esportiva, tanto pescadores quanto empresários afirmam que o município tem potencial para o desenvolvimento da atividade de pesca esportiva, devido à variedade de peixes e pela potencialidade que o Rio Branco, e os demais rios, lagos e igarapés, todos com belas paisagens, apresentam como atrativos e como lugares propícios à pesca esportiva. Uma região em que o turismo é ainda incipiente, mas com evidências de expansão, um lugar onde se pratica desde o 'turismo de observação de pássaros' até a focagem de jacarés, sem se mencionar a pesca per se.

Nessa perspectiva, destaca-se que as localidades da região do Baixo Rio Branco - incluindo-se aí o próprio espaço das vilas ribeirinhas - apresentam grande potencial para o turismo de pesca esportiva se comparado com trechos do rio da área urbana de Caracaraí, e com a pesca nas Corredeiras do BemQuerer, pois nessas localidades não há grande quantidade de peixes, e não são de tamanho tão expressivo. Já no Baixo Rio Branco, há relatos de captura de peixes, filhote e pirarara, com mais de $120 \mathrm{~kg}$. Com base nesses depoimentos, pode-se concluir que o turismo de pesca esportiva pode ser uma alternativa para a sazonalidade da pesca profissional, pois se apresenta como uma saída para a geração de renda, cuja rentabilidade pode superar a da pesca profissional, pois o preço pago pelo pescado é baixo, e há intermediários no processo.

Conforme mencionado anteriormente, a pesca esportiva é uma alternativa viável para geração de renda aos pescadores profissionais, porém ressaltam que algumas medidas precisam ser tomadas pelo poder público, IBAMA, SEBRAE, FEMACT, empresários locais, e associação de pescadores, para discutirem formas de atuação dos pescadores profissionais no desenvolvimento do turismo de pesca esportiva.

Cabe frisar que de acordo com os depoimentos dos empresários, 83\% dos pescadores e comunidade são beneficiados com a pesca esportiva, mas na realidade a atividade ainda não é bastante desenvolvida, visto que o poder público não investe diretamente no setor turístico. A pesquisa revela ainda a inexistência de uma atuação mais marcante e permanente por parte do poder público no sentido de promover campanhas e atuar in situ junto às comunidades 
por meio de cursos de capacitação, orientação técnica, conscientização e educação ambiental.

Para se ter êxito com a pesca esportiva e para a promoção da conservação e preservação do meio ambiente paralelamente a uma melhoria da qualidade de vida dos pescadores e ribeirinhos do Baixo Rio Branco, tais aspectos não podem ser negligenciados pelo poder público, e as parcerias com os grupos de empresários também devem ser incentivadas de modo que as comunidades sejam não competidoras, mas grupos aliados e protagonistas do seu próprio desenvolvimento socioeconômico.

Conforme a pesquisa, a atividade de turismo de pesca esportiva no município de Caracaraí poderá contribuir e beneficiar economicamente tanto a sede quanto as comunidades, pois os turistas deixam divisas no município gerando emprego, contratando os mais diferentes serviços de pessoas para trabalharem no ramo turístico. Contudo, as comunidades locais - exceto por aquelas pessoas que atuam diretamente na pesca esportiva - ainda não perceberam nenhum benefício significativo relacionado com a atividade no município, o que denota a necessidade de intervenções do poder público para se criar um cenário em que o turismo tenha um papel 'social' mais extenso, bem como ações para se divulgar e fortalecer Roraima como destino; um destino turístico de base sustentável e devidamente planejado em cooperação e parceiras com todos os setores e grupos humanos envolvidos.

Por fim, a pesquisa leva à conclusão que o município de fato tem potencial para atividade de pesca esportiva a ser explorado ao passo e esse pode contribuir de várias formas para diminuir o impacto predatório se planejado e praticado sob um viés sustentável, com conscientização e educação ambiental junto às comunidades, bem como com os grupos de empresários, pescadores profissionais, e amadores, a fim de que haja uma postura de compromisso com a preservação das espécies, dos recursos hídricos e naturais, incluindo os atrativos de beleza cênica. Portanto, a pesca esportiva pode servir como um dos meios para se aumentar a conscientização ambiental nos mais diferentes níveis da sociedade, proporcionando grandes emoções em termos de aventura e de lazer ao turista, e possibilitando ao pescador profissional uma fonte de arrecadação alternativa condizente e justa, seja como guia ou integrante da equipe de pesca esportiva.

\section{Referências Bibliográficas}

ANDRADE, J.V. Turismo fundamentação e dimensões. São Paulo 2004. AGRIPA, F.A.; KRISCHKE, P.J. Aspectos da Instituição das Políticas de Sustentabilidade no Brasil. Florianópolis, 2006.

ALBANO, C. J.; VASCONCELOS,E. C. de. Análise de casos de pesca esportiva no Brasil e propostas de gestão ambiental para o setor. Revista Brasileira de Ciências Ambientais, n.28, pp. 77-89, jun. 2013, p.

BARTHOLO, R.; SANSOLO, D.G.; BURSZTYN, I. (Orgs.). Turismo de base comunitária: diversidade de olhares e experiências brasileiras. Rio de Janeiro: Letra e Imagem, 2009.

BENI, M.C. Análise Estrutural do Turismo. São Paulo: SENAC, 1997. 
BENI, M.C. Megatendências do Setor e a Realidade Brasileira. São Paulo: Aleph, 2003.

BOAS, J.H.V. Breve análise da recente dinâmica territorial no estado de Roraima. Nov. 2008.

BRASIL. Ministério do Turismo. Meu negócio é Turismo. ed. Fundação Roberto Marinho. Brasília, 2001.

BRASIL. Ministério do Turismo. Segmentação do Turismo: Marcos conceituais. Brasília, 2006.

BRASIL. Ministério do Turismo. Turismo de pesca: orientações básicas. Brasília, 2008.

CARACARAÍ. Caracaraí-RR-Informações. Disponível em:

<http://www.ferias tur.br /informações/caracaraí-rr> Acesso em: 20. 082011.

CONSTITUIÇÃO DA REPÚBLICA FEDERATIVA DO BRASIL. Texto Constitucional promulgado em 5 de outubro de 1998. Brasília: Senado Federal, 2008.

COOKE, S. J.; COWX, I. G. The role of recreational fishing in global fish crises. BioScience, v. 54, n. 9, p. 857-859, 2004.

CORIOLANO, L.N.M.T. O turismo comunitário no nordeste brasileiro. In: BARTHOLO, R.; SANSOLO, D.G.; BURSZTYN, I. (orgs.). Turismo de base comunitária: diversidade de olhares e experiências brasileiras. Brasília: Letra e Imagem, 2009. p.277-288.

DENCKER, A.F.M. Método de Técnicas de Pesquisa em Turismo: $5^{\text {a }}$ ed. Futura - São Paulo, 2001.

EMBRATUR. Oficina Nacional de Turismo de Pesca. Brasília: 2005.

FECOMERCIO. Roraima: economia e mercado. Dados econômicos e sociais. Boa Vista, 2003.

FREITAS, A. Geografia e História de Roraima. $1^{\underline{a}}$ Ed. Editora Grafima. Manaus-AM, 1997.

GUIA RORAIMA: Ecologia, História e Cultura. Empresa das Artes. Boa Vista: editare, 2010.

INSTITUTO BRASILEIRO DO MEIO AMBIENTE E DOS RECURSOS NATURAIS RENOVÁVEIS - IBAMA. NEA-RR, Ciclo de Palestras: A Educação Ambiental na visão do IBAMA. Realizada em maio de 2009.

INSTITUTO BRASILEIRO DE GEOGRAFIA E ESTATÍSTICA - IBGE. Pesquisa de Informações Básicas Municipais: Perfil dos Municípios Brasileiros. Meio Ambiente. 2010. Disponível em <http://www.ibge.gov.br/> Acesso em 07/10/2012.

JATOBÁ, S.U.S; CIDADE, L.C.F; VARGAS, G.M. Ecologismo, Ambientalismo e Ecologia Política, Brasília, 2009.

KOURY C. G. et al. - Anais do XVII Congresso Brasileiro de Engenharia de Pesca, Participação e Envolvimento Comunitário na Pesca Esportiva na RDS do Uatumã. - Manaus: IDESAM, 2011.

MINISTERIO DA PESCA E AQUICULTURA - MPA. Amazonia Aquicultura e Pesca. Brasília, 2011. 
MINISTÉRIO DO TURISMO. Diretrizes para o desenvolvimento do Turismo Rural. Brasília: 2003. REVISTA TURISMO. Ética, turismo e mercado de trabalho. Disponível em: $<$ http://www.revistaturismo.com.br/artigos/etica.html>. Acesso em: 02 setembro 2012.

RORAIMA. SEPLAN /DEMA Leis, Decretos e Códigos de Proteção ao Meio Ambiente do Estado de Roraima. Ed. atual. Boa Vista, 2002.

SANTOS JUNIOR, A.P.; RIBEIRO, J.D.A. Análise dos impactos ambientais do turismo em uma área protegida na Amazônia. Disponível em: http://www.cadernovirtualdeturismo.com Acesso em: 05 de março 2012.

SCORSATO, S.M. Hospitalidade: o desafio das populações de pescadores que se transformam em fornecedores de serviços turísticos. São Paulo: Primavera, 2006.

SEMMA. Secretaria Municipal de Meio Ambiente de Caracaraí. Inventário de Caracaraí. Caracaraí, 2009.

SILVA, S.B.; SILVA, B.C. Roraima: problemas de desenvolvimento sustentável em uma região de fronteira. Rio de Janeiro, 2005.

STOECKL, N.; GREINER, R.; MAYOCCHI, C. The community impacts of different types of visitors: an empirical investigation of tourism in North-west Queensland. Tourism Management, v. 27, n. 1, p. 97-112, Feb 2006.

Eliane Inácio da Silva: Universidade Estadual de Roraima, Boa Vista, RR, Brasil.

E-mail: elianeinacio3@hotmail.com

Link para o currículo Lattes: http://lattes.cnpq.br/4456534665531904

Ismar Borges de Lima: Universidade Estadual de Roraima, Boa Vista, RR, Brasil.

E-mail: ismarlima@yahoo.com.br

Link para o currículo Lattes: http://lattes.cnpq.br/1226725450970361

Data de submissão: 03 de julho de 2013

Data de recebimento de correções: 03 de julho de 2013

Data do aceite: 20 de outubro de 2014

Avaliado anonimamente 